\title{
TCOM \\ Co-benefits associated with public support for climate-friendly COVID-19 recovery policies and political activism
}

\section{Jagadish Thaker and Brian Floyd}

\begin{abstract}
Scientists highlight that actions that address environmental protection and climate change can also help with reducing infectious disease threats. Results using data from a national sample survey in New Zealand indicate that perceptions of co-benefits of actions to address environmental protection that also protect against infectious disease outbreaks such as the coronavirus is associated with policy support and political engagement. This association was partly mediated through perceived collective efficacy. Local councils with higher level of community collective efficacy were more likely to declare climate emergency. Communication about potential co-benefits is likely to shape public engagement and enact policy change.
\end{abstract}

Keywords Environmental communication; Health communication

DOI

https://doi.org/10.22323/2.20050208

Submitted: 18th March 2021

Accepted: 20th July 2021

Published: 4th October 2021

Context and objectives
The coronavirus disease 2019 (COVID-19) pandemic has resulted in an unparalleled impact on public health and economy, with over 3.82 million deaths and 176 million cases worldwide as of June 2021. According to the World Health Organization (WHO), "most emerging infectious diseases, and almost all recent pandemics, originate in wildlife, and there is evidence that increasing human pressure on the natural environment may drive disease emergence" [World Health Organization, 2020, para. 3]. A recent report by WHO states that the virus that causes COVID-19 was most likely transmitted from wild bats to humans through another animal, even as further evidence is collected [World Health Organization, 2021]. Environmental destruction and climate change are primary drivers of rise in infectious diseases such as malaria, dengue and chikungunya fevers, leptospirosis, cryptospirosis, hantavirus fever, Rift Valley fever, norovirus infections, and Q-fever [Semenza et al., 2016].

Public health experts and economists argue that actions to prevent the rise in infectious disease outbreaks are much the same as to prevent climate change [Hepburn et al., 2020]. For example, reducing the root causes of climate change 
such as deforestation will also help prevent infectious diseases jumping from wildlife to humans due to increased human-animal contact [Brancalion et al., 2020; Keesing et al., 2010]. Similarly, reducing air pollution will help protect against respiratory infections such as COVID-19 as air pollution is estimated to have contributed to about 15\% COVID-19 mortality worldwide, ranging from $27 \%$ in East Asia to $17 \%$ in North America [Pozzer et al., 2020]. The cascading effects of climate change related extreme weather events such as floods result in infectious disease outbreaks through water and food contamination [Suk et al., 2020]. Moreover, extreme weather events such as heatwaves, hurricanes, floods during a pandemic result in human displacement and affect disaster preparedness and recovery [Centers for Disease Control and Prevention, 2021].

Recently, 350 organizations representing over 40 million health professionals wrote to governments to prioritize investments in health, clean air and water, and a stable climate in stimulus packages for recovering from the Covid-19 pandemic (https:/ / healthyrecovery.net). Scholars have identified five clean and green COVID-19 economic recovery policies that deliver on both economic recovery and climate action: clean physical infrastructure, building efficiency retrofits, investment in education and training, natural capital investment, and clean energy research and development [Hepburn et al., 2020]. Such policies not only provide stimulus to the economy recovering from short-term impacts of COVID-19 disruption but help achieve long-term target of net zero emissions. Public support in enacting and implementing these policies is critical to achieving success as public opinion shapes government enactment of environmental policies [e.g., Anderson, Böhmelt and Ward, 2017; Hepburn et al., 2020].

However, over three decades of increasing scientific consensus has not resulted in commensurate public and policy action to mitigate and adapt to the impacts of climate change. Greenhouse gas emissions in New Zealand, a country more famously advertised as "100\% natural" in its marketing campaign, has increased by $24 \%$ since 1990 . One way to improve public understanding and engagement with climate change is to communicate the co-benefits of climate action as also resulting in better outcomes on important issues that resonates with the public, such as health, environment, economy, and national security [Akerlof et al., 2020; Amelung et al., 2019; Bain et al., 2016; Hart and Feldman, 2018; Maibach et al., 2010; Myers et al., 2012].

A public health co-benefits frame that highlights the human health implications of climate change such as protecting individual and public health has appeared to be most promising avenue of research [Kreslake et al., 2018; Maibach et al., 2010]. Over the years, there has been a substantial effort to make public health practitioners to be primary advocates of climate change communication [e.g., Kreslake et al., 2018]. Further, the Lancet Commission on Health and Climate Change underscores that climate change is not only one of the biggest challenges but also the greatest global health opportunity of the $21^{\text {st }}$ century [Watts et al., 2015]. Highlighting co-benefits translates a scientifically abstract and distant issue of climate change as personally relevant and as a result induces individual private action through behavior change and public action through political and civic engagement.

Empirical research examining the effectiveness of communicating the co-benefits of climate actions on public responses have been mixed, however. While some 
scholars find that communicating co-benefits motivates public action on climate change [Amelung et al., 2019; Bain et al., 2016; Myers et al., 2012; Walker, Kurz and Russel, 2018], other studies have found no or little impact [Akerlof et al., 2020; Bernauer and McGrath, 2016; Hart and Feldman, 2018; Li and Su, 2018; McCright and Dunlap, 2011; Singh and Swanson, 2017], even a boomerang effect such that the co-benefits frame increases the partisan gap between the alarmed and the dismissive publics [Hart and Feldman, 2018]. In a meta-analysis of 10 studies, Li and $\mathrm{Su}$ [2018] found that while frames that emphasize environment, economic, and moral dimensions of climate change have a small to medium size impact on individuals' engagement with climate change, message frames around public health implications have no significant association with individual engagement. As a result, some scholars caution promoting health co-benefits as it likely amplifies the partisan gap [Hart and Feldman, 2018], instead suggesting to keep the focus on climate risk reduction [Bernauer and McGrath, 2016]. A number of factors are suggested to help explain the potential and the pitfalls of communicating co-benefits of climate change, including selective exposure, cognitive dissonance, emotional incongruence, among others.

Compared to previous localized health impacts, however, the coronavirus pandemic provides a more global visceral experience. Apart from deaths of family and friends, the nature of lockdown in different countries, with restricted travel not just across borders but across neighborhoods, provided a powerful personal experience with a global issue. Individuals potentially learned vicariously about the human impact on the environment through viral images of animals occupying city streets [Chalasani, 2020] and clear skies even in most polluted cities [Gettleman and Conway, 2020]. This is in line with other surveys that show that public concern about climate change has increased after COVID-19 [Morton, 2020; Poushter and Huang, 2020].

This study adds to the above literature on the mixed findings of co-benefits framing on citizens engagement in several unique ways. First, a majority of these studies have utilized experiments, which may result in short-term impact, with limited evaluation through public opinion surveys. In contrast, by directly assessing public understanding of co-benefits would help assess salience of co-benefits as well as co-morbidities associated with climate change impacts in the public mind.

Moreover, many studies have focused on policy support, whereas political activism is equally important in driving policy change [Roser-Renouf, Atkinson et al., 2016]. Political activism is required for policy support to translate into policy change.

Second, a primary limitation of these studies has been inconsistency in testing the efficacy of co-benefit frames on shaping public opinion. While some studies incorporate climate change and public health frame in the same message [Bernauer and McGrath, 2016; Feldman and Hart, 2018; Myers et al., 2012], other scholars have presented this information sequentially [Bain et al., 2016; Walker, Kurz and Russel, 2018] or have used frame substitution where climate change is not mentioned at all [Hart and Feldman, 2018; Walker, Kurz and Russel, 2018]. Indeed, when scholars have tested both climate and non-climate information on health and environment impacts, they find that while non-climate information (air pollution vs climate change) triggers public support, there is no difference between emphasizing health or environment impacts resulting from such causes [Hart and Feldman, 2018]. One of the most cited papers on the importance of co-benefits to 
motivate public action asked respondents to imagine a future where mitigation has been completely or partly successful, as an after-effect of climate action [Bain et al., 2016]. The variability of findings could potentially be a result of this inconsistency in measurement. Measuring public understanding about co-benefits for climate action - and co-impacts for inaction - provides a more reliable measure. Co-impacts here is defined as added negative impacts due to climate inaction, such as extreme weather events during a pandemic, adding additional stress on the system [Centers for Disease Control and Prevention, 2021].

Third, a majority of these studies have either focused on co-benefits exposure to result in emotions [Myers et al., 2012] or have used emotional reactions as a mediator between co-benefits frames and public engagement [Nabi, Gustafson and Jensen, 2018]. While emotions play an important role in heightening certain aspects of an issue, they are also likely to result in a short-term impact. At the same time, several prominent theories such as the extended parallel process model [Witte, 1992] and social cognitive theory [Bandura, 2000; Bandura, 2001] highlight that efficacy is a more proximal source of influence on behaviors. This study tests if the association between co-benefit frames and public engagement is mediated through collective efficacy, in part by increasing perceptions about collective control and perceived ability to collectively organize and enact on issues that individuals consider as personally relevant. Climate change, ultimately, is a collective problem [Ostrom, 2010]. Few individuals enacting beneficial actions are important but not a sufficient condition for change that is commensurate with the global challenge of climate change.

Finally, an overwhelming majority of studies test self-reported behavioral intentions and policy support, with little external validity. In addition, most of the research on the influence of communicating co-benefits on climate activism, as mentioned above, has been limited to the U.S. The current study addresses these limitations by testing if public self-reports are associated with local government councils' decisions about climate change, namely declaring climate emergency. Local councils declaring climate emergency makes climate change a central tenet in making local government decisions about funding priorities. These hypotheses are tested using a nationally representative sample in New Zealand, a country whose emissions have increased by $24 \%$ between 1990 and 2018. At the same time, New Zealand has witnessed important policy change such as the Zero Carbon Act, which aims to reduce net emissions of all greenhouse gases (except biogenic methane) to zero by 2050 .

\section{Co-benefits and public response}

Framing is a central theoretical framework to examine ways to increase public understanding and engagement with climate change [Chong and Druckman, 2007; Feldman and Hart, 2018; Nisbet, 2009; Scheufele, 1999]. Framing is "to select some aspects of a perceived reality and make them more salient in a communicating text, in such a way as to promote a particular problem definition, causal interpretation, moral evaluation, and/or treatment recommendation..." [Entman, 2002, p. 52]. Framing operates through applicability effect [Price and Tewksbury, 1997], in that frames increase the alignment between information provided and personal relevance. 
Among studies that have tested different framing effects on public response, co-benefits of a health frame has been the focus of several studies. Myers et al. [2012] found that a public health frame elicited hopeful emotions, whereas a national security frame generated an angry backlash among the audience segments who were doubtful or dismissive of climate change. The environment frame - the most dominant frame of climate change in the media and communication campaigns - resulted in neither anger nor hope among such segments. Their study did not test public support for policy or willingness for behavior change, however.

Nabi, Gustafson and Jensen [2018] tested if gain- ("Stopping climate change will benefit U.S. health") versus loss-framed efficacy messages ("Not stopping climate change threatens U.S. health") resulted in emotions favorable for climate engagement. They found that a gain-framed message evoked hope while a loss-framed message evoked fear, which in turn was associated with favorable attitudes towards climate policies and advocacy behaviors such as signing e-petitions. In particular, they found that messages that evoked fear and then hope had the strongest positive influence on advocacy behavior compared to a message that lacked emotional flow.

Walker and colleagues [2018] found that framing car-use reduction policy in terms of primarily public health benefits (as opposed to primarily climate change benefits) resulted in greater policy support. Amelung et al. [2019] found that compared to the sample which received information about benefits of mitigation and financial savings, information on direct health co-benefits was associated with a higher willingness to adopt mitigation actions. Using convivence samples from 24 countries $(N=6196)$, Bain et al. [2016] found that co-benefits related to economic and scientific development and benevolence motivated public, private, and financial actions to address climate change. However, more commonly cited co-benefits addressing health impacts such as pollution and disease were weakest motivators for public action on climate change. They conclude that communicating the co-benefits of addressing climate change can foster public action, even among those who are skeptical about the reality of climate change.

At the same time, however, researchers find no association or boomerang effects between perceptions of co-benefits of climate action and individual mitigation behaviors. Feldman and Hart [2018] used an online experiment to test audience reactions to co-benefits frames. When individuals' choice of news stories was restricted to articles on climate change, participants were more likely to select stories that focus on human health impacts of climate change, relative to other frames that emphasized co-benefits of climate change on national security, economic, or moral dimensions. However, these effects were absent for conservative-Republicans. When allowed a choice to select news stories, conservative-Republicans were significantly less likely than liberal-Democrats to read climate news when it was framed in terms of human health or national security.

Gromet and colleagues [2013] found that more conservative individuals were less likely to purchase a more expensive energy efficient light bulb when it was labeled with an environmental message than when it was unlabeled. Bernauer and McGrath [2016] conducted survey embedded experiment in a U.S. sample to test if 
relative to a climate risk reduction frame - emphasizing potential risks due to inaction - do economic co-benefits frame, a community building frame, or a health benefits frame is associated with behavioral intentions, policy support, and environmental citizenship. They found higher willingness for top-down policies than individual behavioral intentions or environmental citizenship, indicating that even among respondents aware of the climate change problem would nevertheless prefer government actions over individual action. Respondents who did not believe climate change is a serious problem overwhelmingly disapproved of active personal engagement. Moreover, they found no significant differences in frames in influencing individual actions, either between climate skeptics or non-skeptics.

These studies, using different methodologies, have found mixed effects on the impact of health frame about climate change on behavioral change and policy support. However, few studies have found positive associations and there is a need to test if co-benefits resonate with publics outside the U.S. As mentioned above, compared to previous health impacts, the coronavirus pandemic provides a more global visceral experience. As public health experts, economists, and sustainable development experts argued, COVID-19 presents an opportunity to address the immediate impact of COVID-19 along with long-term issues of environmental protection and climate change, or a clean and green COVID-19 economic recovery policies. Based on these studies, the following hypotheses are tested:

H1a: Perceptions about co-benefits of actions to address environmental protection and coronavirus will be positively associated with support for clean and green COVID-19 economic recovery policies.

H1b: Perceptions about co-benefits of actions to address environmental protection and coronavirus will be positively associated with political engagement.

H2a: Perceptions about co-impacts of extreme weather events on coronavirus response will be positively associated with support for clean and green COVID-19 economic recovery policies.

H2b: Perceptions about co-impacts of extreme weather events on coronavirus response will be positively associated with political engagement.

\section{Collective efficacy}

According to social cognitive theory, perceptions about self- and collective abilities are primary motivators of individual and collective action [Bandura, 2000; Bandura, 2001]. Self-efficacy can be defined as belief in one's ability to perform certain behaviors.. A number of studies show that messages that contain threat alone do not motivate public action on climate change. Instead, messages that promote efficacy perceptions are likely to motivate public engagement [Hart and Feldman, 2016; Milfont, 2012; Roser-Renouf, Maibach et al., 2014]. While these studies provide evidence on the important relationship between self-efficacy and political behavior, they do not focus on collective efficacy and policy support. While individual-level efficacy is important and is positively associated with perceptions of collective efficacy, public perceptions about their collective abilities have more predictive value when tasks require coordination and collective action [Lee, 2006; Velasquez and LaRose, 2015]. Chen [2015] found that compared with 
self-efficacy, collective efficacy is a stronger predictor of people's problem-focused coping and self-reported proenvironmental behavior in Taiwan.

Collective efficacy is defined as an individual's belief in the collective capabilities of their group to organize and perform collective tasks in order to achieve group goals [Bandura, 2001]. Efficacy beliefs govern how individuals feel, think, motivate themselves, mobilize and pool in their resources needed to succeed in their group endeavors. An increasing body of evidence attests that collective efficacy are important to achieve common goals. Reviewing the work on collective efficacy and health outcomes, Bandura [1998, p. 646] noted, "A comprehensive approach to health must provide people with the knowledge, skills and sense of collective efficacy to mount social and policy initiatives that affect human health".

Governments are collective entities where citizens come together and enact policies to achieve their collective goals, in this case to respond to COVID-19 and climate change. Previous research show that individual's collective efficacy beliefs are associated with both traditional political engagement such as policy support as well as more confrontational tactics such as protests for policy change [Roser-Renouf, Maibach et al., 2014; Thaker et al., 2016].

Based on these theoretical and empirical findings, the following hypotheses are proposed:

H3a: Perceived collective efficacy will be positively associated with support for clean and green COVID-19 economic recovery policies.

H3b: Perceived collective efficacy will be positively associated with political engagement.

\section{Co-benefits and collective efficacy}

Little research is focused on why perceptions about co-benefits can potentially motivate public action on climate change. One pathway that scholars have assessed is that reframing climate action as resulting in better societal outcomes makes the issue of climate change more personally relevant and emotionally engaging [e.g., Bernauer and McGrath, 2016]. Yet, a crucial link connecting individual behaviors that result in collective good has often been sidelined, namely the issue of collective action problem or free-riding. That is, individuals are either uncertain or unconvinced if their individual actions will be sufficient to generate collective outcomes such as reduced pollution, reduced risk of climate impacts [Amelung et al., 2019]. In other words, research that finds that co-benefits does not result in increased public willingness to act on climate change is either a result of lack of personal relevance or lack of investing in collective good. Amelung et al. [2019] also argued that studies that find an association between a co-benefits frame are uncertain if the mechanism is either through increased belief in the co-benefits argument or willingness to do a common public good. It is possible that sufficiently large benefits from a climate policy can potentially offset concerns about free-rider effect [Bernauer and McGrath, 2016], yet requires collective action to enact policy change and for successful implementation of such policies.

This study argues that one of the pathways that co-benefits frame can help improve public engagement is through collective efficacy, or beliefs that people together can 
act to achieve a common goal. Understanding co-benefits for climate action can increase perceptions about benefits of co-joint efforts. Previous research in the domains of health communication and environmental communication [Morton et al., 2011] indicate efficacy beliefs mediate the association between information exposure and climate change beliefs on one-hand, and behavioral responses on the other. For example, Morton and colleagues [2011] found that perceived collective efficacy mediated the association between framing effects and behavioral intentions such that in the face of high uncertainty, positively framed messages increased intentions for action as a result of heightened efficacy. They concluded that uncertainty is not an inevitable barrier for climate change communication; instead, gain framed messages result in increased efficacy beliefs, which in turn, are associated with higher motivation for individual action. Other studies also show that efficacy beliefs mediate spillover from easy to more difficult environmental behaviors [Lauren et al., 2016]. Spence et al. [2011] found that efficacy beliefs mediated the association between flooding experience and behavioral intentions to reduce energy use. Bostrom, Hayes and Crosman [2019] found that while concern fully mediates the relatively strong effects of perceived risk on policy support, concern only partly mediates efficacy beliefs association with policy support. That is, the impact of both self-efficacy and collective efficacy on policy support is direct rather than indirect. Based on these findings, the following hypotheses are tested:

H4a: Perceived collective efficacy will mediate the association between perceptions about co-benefits of actions to address environmental protection and coronavirus with support for clean and green COVID-19 economic recovery policies.

H4b: Perceived collective efficacy will mediate the association between perceptions about co-impacts of extreme weather events on coronavirus response with clean and green COVID-19 economic recovery policies.

\section{Community collective efficacy and local government}

Finally, this study tests if collective efficacy, at the community-level, is associated with community-level outcomes, such as local councils' declaring climate emergency. This is because, high group collective efficacy establishes a strong normative influence of the group that affects how groups plans, overcome barriers, and pool their resources to ensure group goal achievement [Goddard, Hoy and Hoy, 2004; Thaker et al., 2016]. In many ways, local government bodies are at the forefront of climate impacts. In New Zealand, there are 72 councils out of which 16 councils have declared climate emergency as of 2020 [Controller and Auditor-General, 2020].

H5: Community collective efficacy will be positively associated with local councils' declaration of climate emergency.

Methods

The data for this study comes from a nationally representative sample survey of 1040 New Zealand adults, aged 18 and older. The self-administered web-based survey was fielded by Qualtrics, an international survey agency, between June 26 to July 13, 2020, just after New Zealand's national lockdown was lifted and the 
Table 1. Demographic characteristics of the sample.

\begin{tabular}{|c|c|c|c|c|}
\hline & $\begin{array}{c}N \\
\text { (unweighted) }\end{array}$ & $\begin{array}{c}\% \\
\text { (unweighted) }\end{array}$ & $\begin{array}{c}\% \\
\text { (weighted) }\end{array}$ & $\begin{array}{l}\% \text { census } \\
\text { estimate }\end{array}$ \\
\hline Total & 1040 & 100 & 100 & 100 \\
\hline \multicolumn{5}{|l|}{ Sex } \\
\hline Female & 609 & 58.6 & 51 & 50.6 \\
\hline Male & 431 & 41.4 & 49 & 49.3 \\
\hline \multicolumn{5}{|l|}{ Age } \\
\hline $18-25$ & 189 & 18.2 & 14 & 14 \\
\hline $26-35$ & 220 & 21.2 & 18 & 18 \\
\hline $36-45$ & 175 & 16.8 & 16 & 16 \\
\hline $46-55$ & 163 & 15.7 & 18 & 18 \\
\hline $56-65$ & 127 & 12.2 & 15 & 15 \\
\hline 66 and above & 166 & 16 & 19 & 19 \\
\hline \multicolumn{5}{|l|}{ Education } \\
\hline No qualification & 96 & 9.2 & 19 & 18.19 \\
\hline Level 1 to Level 6 diploma & 577 & 55.5 & 54 & 51.10 \\
\hline Bachelor's degree or higher & 367 & 35.3 & 27 & $24.82^{*}$ \\
\hline \multicolumn{5}{|l|}{ Ethnicity } \\
\hline European New Zealander & 648 & 62.3 & 61.5 & 64 \\
\hline Māori & 139 & 13.4 & 16.3 & 17 \\
\hline Pasifika & 50 & 4.8 & 7.7 & 8 \\
\hline Asian or other & 203 & 19.5 & 14.4 & 15.1 \\
\hline
\end{tabular}

Note: $N=1040$. Data was weighted on sex, age, ethnicity, and education. The census estimates according to 2018 census (https:/ / www.stats.govt.nz/2018-census/). * Percentages do not add to $100 \%$ as some responses were unidentifiable or not stated in the Census.

country returned to some degree of normality. The survey took about 22 minutes on average to complete. The data were weighted, post-survey, on gender, age, education, and ethnicity to match the New Zealand census estimates. See Table 1 for a summary of demographic variables.

The wording of the questions, the range of responses, and other descriptive information is provided in Table 2 . The dependent variable of mitigation policy support variables were operationalized based on the Oxford University study that identified five top policy measures that address economic recovery from COVID-19 in alignment with climate action [Hepburn et al., 2020]. These policy support items particularly referenced to the government's emergency funding to deal with the COVID-19, with implications for climate action. Principal axis factor analysis with direct oblimin rotation, to account for correlation between the variables, was used to verify if the variables represent distinct factors. Kaiser-Meyer-Olkin measure of sampling adequacy was 0.92 , above the commonly recommended value of .6 , and Bartlett's test of sphericity was significant $\left(\chi^{2}(28)=4013.54, p<.001\right)$. All the items loaded on one factor that explained $58 \%$ of the variance. The mean of the variables was computed to represent policy support measure.

The second dependent variable of political engagement were sourced from a recent survey in the U.S. [Leiserowitz, Maibach, Rosenthal, Kotcher, Bergquist et al., 2019] (see Table 2). The items to measure collective efficacy and political participation 
[Leiserowitz, Maibach, Rosenthal, Kotcher, Ballew et al., 2020] were adapted from recent surveys in the U.S. Respondents within a geographical area that represented local councils were used to aggregate individuals' collective efficacy perceptions to compute community collective efficacy and test its association with local councils' climate emergency declaration.

Several demographic variables were controlled for in the study, including, gender, age, income, education. The following variables were dummy coded: marital status (married/with partner, de-facto $=1$, versus others coded as 0 ), those with children (1), job status (currently employed =1), membership in local groups (yes =1), and smoking status (smoke/roll own tobacco/vape =1). Group membership was used to account for networks of social support and learning, and smoking status was used to account for higher susceptibility to COVID-19 disease. Asian and other ethnicities were dummy coded in reference to European New Zealanders (European descendants or white), Māori, and Pasifika.

Hypotheses were tested using hierarchical regression models. The mediation analysis were tested using the PROCESS macro for regression-based estimation

Table 2. Measures.

\begin{tabular}{|c|c|c|c|}
\hline Items & $M(S D)$ & $\alpha$ & $r$ \\
\hline $\begin{array}{l}\text { Co-benefits of environmental protection on coronavirus } \\
\text { response }\end{array}$ & $2.77(.76)$ & 0.77 & $\begin{array}{l}.44 \text { to } .58 \\
p<.001\end{array}$ \\
\hline \multicolumn{4}{|l|}{ How much do you agree or disagree with the following statements? } \\
\hline $\begin{array}{l}\text { Reducing air pollution caused by burning fossil fuels like coal, } \\
\text { oil and natural gas protects us from respiratory infections like } \\
\text { the coronavirus }\end{array}$ & $2.56(0.95)$ & & \\
\hline $\begin{array}{l}\text { Greater protection of plant and animal species reduces the risks } \\
\text { of future outbreaks of new diseases such as the coronavirus }\end{array}$ & $2.69(0.93)$ & & \\
\hline $\begin{array}{l}\text { We cannot protect our health without protecting the } \\
\text { environment }\end{array}$ & $3.06(0.87)$ & & \\
\hline Co-benefits of extreme weather events on coronavirus response & $2.94(.71)$ & 0.76 & $\begin{array}{l}.44 \text { to } .65 \\
p<.001\end{array}$ \\
\hline \multicolumn{4}{|l|}{ How much do you agree or disagree with the following statements? } \\
\hline $\begin{array}{l}\text { Extreme weather events such as hurricanes and floods make it } \\
\text { harder to treat diseases like the coronavirus because it places } \\
\text { more strain on hospitals }\end{array}$ & $3.12(0.83)$ & & \\
\hline $\begin{array}{l}\text { Extreme weather events increase the spread of diseases such as } \\
\text { the coronavirus when people displaced from their homes } \\
\text { crowd into shelters }\end{array}$ & $3.15(0.83)$ & & \\
\hline $\begin{array}{l}\text { Increasing temperatures due to climate change make it difficult } \\
\text { to practise preventive behaviours against the coronavirus }\end{array}$ & $2.56(0.93)$ & & \\
\hline Collective efficacy & $2.67(1.11)$ & 0.94 & $\begin{array}{l}.72 \text { to } .84 \\
p<.001\end{array}$ \\
\hline \multicolumn{4}{|l|}{ How confident are you that people like you, working together, can } \\
\hline $\begin{array}{l}\text { affect what local businesses in your community do about } \\
\text { climate change }\end{array}$ & $2.78(1.17)$ & & \\
\hline affect what your local council does about global warming & $2.66(1.19)$ & & \\
\hline affect what the government does about global warming & $2.68(1.23)$ & & \\
\hline affect what corporations do about climate change & $2.54(1.24)$ & & \\
\hline
\end{tabular}


Table 2. Continued from the previous page.

\begin{tabular}{|c|c|c|c|}
\hline Items & $M(S D)$ & $\alpha$ & $r$ \\
\hline Policy support & $2.94(0.89)$ & 0.89 & $\begin{array}{l}.39 \text { to } .70 \\
p<.001\end{array}$ \\
\hline \multicolumn{4}{|l|}{$\begin{array}{l}\text { How much do you support or oppose how this government's } \\
\text { emergency funding is spent? }\end{array}$} \\
\hline $\begin{array}{l}\text { Forest restoration should be the primary goal of government } \\
\text { funding }\end{array}$ & $3.1(1.13)$ & & \\
\hline $\begin{array}{l}\text { Most the government funding should go to provide tax credits } \\
\text { and subsidies to individuals who purchase electric cars or } \\
\text { trucks }\end{array}$ & $2.48(1.21)$ & & \\
\hline $\begin{array}{l}\text { Funding for retail sector only if they plan to reduce their } \\
\text { pollution and waste }\end{array}$ & $2.82(1.14)$ & & \\
\hline $\begin{array}{l}\text { Providing tax credits or rebates to individuals to improve } \\
\text { energy efficiency of their homes should be the priority of } \\
\text { government funding }\end{array}$ & $3.06(1.17)$ & & \\
\hline $\begin{array}{l}\text { Government should spend more money to improve and } \\
\text { expand walking paths, cycling lanes }\end{array}$ & $2.69(1.21)$ & & \\
\hline $\begin{array}{l}\text { Most of the funding in transportation sector should go to } \\
\text { improve public transportation and rail infrastructure }\end{array}$ & $3.27(1.14)$ & & \\
\hline $\begin{array}{l}\text { Most of education funding should go for training for jobs in } \\
\text { renewable energy industries }\end{array}$ & $2.94(1.15)$ & & \\
\hline $\begin{array}{l}\text { Most of government support should be to research clean } \\
\text { technologies such as solar and wind power }\end{array}$ & $3.19(1.17)$ & & \\
\hline Political engagement & $2.09(0.85)$ & 0.88 & $\begin{array}{l}.63 \text { to } .71 \\
p<.001\end{array}$ \\
\hline \multicolumn{4}{|l|}{$\begin{array}{l}\text { How likely would you do the following behaviours in the next } 12 \\
\text { months? }\end{array}$} \\
\hline $\begin{array}{l}\text { Write letters, email, or phone government officials urging } \\
\text { action against climate change }\end{array}$ & $2.21(1.00)$ & & \\
\hline Donate money to an organisation working on climate change & $2.24(0.97)$ & & \\
\hline $\begin{array}{l}\text { Personally engage in non-violent civil disobedience (e.g., } \\
\text { sit-ins, blockades, or trespassing) against corporate or } \\
\text { government activities that make climate change worse }\end{array}$ & $2.06(1.03)$ & & \\
\hline $\begin{array}{l}\text { Host a neighbourhood meeting in your home to discuss climate } \\
\text { change }\end{array}$ & $1.86(0.95)$ & & \\
\hline
\end{tabular}

Note: $N=1040$. Items 1, 2 and 5 were measured on a four-point scale from $1=$ strongly disagree, $4=$ strongly agree. Item 3 was measured on a five-point scale from $1=$ not at all confidence to $5=$ extremely confident. Item 4 was measured on a five-point scale from $1=$ not at all to $5=$ great deal. The mean of the individual items was computed to represent respective scales.

[Hayes, 2013], and in addition, bootstrapping with 5000 resamples were employed to ensure the robustness of the findings. PROCESS uses a path analytic framework based on OLS regression and bootstraps observed indirect effects. This is considered a superior approach to causal steps or the Sobel test for mediation [Hayes, 2013]. Demographic variables were included as covariates in all mediation analysis. Both the hypothesized paths from co-benefits/co-impacts - collective efficacy - policy support and an alternative model, collective efficacy co-benefits / co-impacts - policy support were tested to assess robustness of findings. In addition, the product of collective efficacy and co-benefits/co-impact variables was also tested on policy support to rule out alternative findings (results not presented due to insignificant results). 
Perceived co-benefits of environment protection on coronavirus response was positively associated with policy support $(r=0.54, p<.001)$ and political engagement $(r=0.49, p<.001)$. Perceived co-impacts of extreme weather events on coronavirus response was positively associated with policy support $(r=0.38$, $p<.001)$ and political engagement $(r=0.32, p<.001)$. Moreover, perceived co-benefits and co-impacts were moderately correlated with each other $(r=0.60$, $p<.001)$. Both co-benefits $(r=0.42, p<.001)$ and co-impacts $(r=0.34, p<.001)$ were significantly and positively associated with perceived collective efficacy. Finally, perceived collective efficacy was positively associated with policy support $(r=0.59 p<.001)$ and political engagement $(r=0.62, p<.001)$.

Table 3 and Table 4 show regression results predicting policy support and political engagement, respectively. Support was found for H1a, perceptions about co-benefits of actions to address environmental protection and coronavirus was positively associated with support for clean and green COVID-19 economic recovery policies $(\beta=.34, p<.001)$. Support was also found for H1b with perceptions about co-benefits positively associated with political engagement on climate change $(\beta=.30, p<.001)$.

Table 3. Regression with policy support as outcome variable.

\begin{tabular}{|lcccccccccc|}
\hline & \multicolumn{3}{c}{ Model 1 } & \multicolumn{3}{c}{ Model 2 } & \multicolumn{3}{c|}{ Model 3 } \\
\hline & $B$ & $S E$ & $\beta$ & $B$ & $S E$ & $\beta$ & $B$ & $S E$ & $\beta$ \\
\hline (Constant) & $3.30^{* * *}$ & 0.17 & & $1.37^{* * *}$ & 0.18 & 0.18 & $0.95^{* * *}$ & 0.16 & 0.16 \\
Female & $-0.11^{*}$ & 0.06 & -0.06 & $-0.17^{* *}$ & 0.05 & -0.09 & $-0.15^{* * *}$ & 0.04 & -0.09 \\
Age & $-0.08^{* * *}$ & 0.02 & -0.16 & $-0.06^{* *}$ & 0.02 & -0.11 & 0.01 & 0.02 & 0.01 \\
Education & $0.11^{*}$ & 0.05 & 0.08 & $0.08^{*}$ & 0.04 & 0.06 & 0.04 & 0.04 & 0.03 \\
European NZ & $-0.21^{*}$ & 0.09 & -0.12 & -0.08 & 0.07 & -0.05 & -0.03 & 0.06 & -0.01 \\
Māori & -0.11 & 0.10 & -0.05 & -0.10 & 0.09 & -0.04 & -0.08 & 0.08 & -0.03 \\
Pasifika & 0.08 & 0.12 & 0.02 & 0.11 & 0.10 & 0.03 & 0.11 & 0.09 & 0.03 \\
Ideology & 0.01 & 0.03 & 0.01 & -0.03 & 0.02 & -0.03 & -0.04 & 0.02 & -0.04 \\
Income & -0.02 & 0.02 & -0.05 & -0.01 & 0.02 & -0.03 & -0.01 & 0.02 & -0.03 \\
Employed & -0.09 & 0.06 & -0.05 & 0.02 & 0.05 & 0.01 & 0.02 & 0.05 & 0.01 \\
Has children & 0.05 & 0.06 & 0.03 & 0.05 & 0.05 & 0.03 & 0.08 & 0.05 & 0.04 \\
Marital status & -0.04 & 0.06 & -0.02 & -0.04 & 0.05 & -0.02 & -0.04 & 0.05 & -0.02 \\
Group membership & 0.03 & 0.06 & 0.01 & 0.07 & 0.05 & 0.04 & -0.03 & 0.04 & -0.01 \\
Smoking status & -0.06 & 0.06 & -0.03 & -0.06 & 0.05 & -0.03 & -0.11 & 0.05 & -0.06 \\
Co-benefits: environmental protection & & & $0.57^{* * *}$ & 0.04 & 0.49 & $0.40^{* * *}$ & 0.04 & 0.34 \\
on coronavirus response & & & & & & & & & \\
Co-impacts: extreme weather events & & $0.10^{*}$ & 0.04 & 0.08 & 0.04 & 0.04 & 0.04 \\
on coronavirus response & & & & & & & $0.36^{* * *}$ & 0.02 & 0.45 \\
Collective efficacy & & & & & & & $0.46^{* * *}$ & & \\
$\Delta R^{2}$ & $0.05^{* * *}$ & & & $0.32^{* * *}$ & & & 266.09 & & \\
F Change & 4.79 & & & 206.38 & & & & \\
\hline
\end{tabular}

Note: $n=1036$. $^{* * *} p<.001,{ }^{* *} p<.01,^{*} p<.05$. Gender was measured dichotomously compared male with female (1). The three ethnicity variables were dummy coded with Asian and other ethnicities coded as a reference category. Employed were coded as 1 for respondents who said they are currently employed compared to others. Parental status was coded as 1 with reference to others (0). Marital status was coded for respondents with a spouse, partner, de-facto, live-in relationship to others. Group membership was coded for respondents who said they belonged to a local club with reference to others. Respondents who smoked, rolled their own cigarettes, or vaped were coded with reference to others. 
Table 4. Regression with political engagement as outcome variable.

\begin{tabular}{|c|c|c|c|c|c|c|c|c|c|}
\hline & \multicolumn{3}{|c|}{ Model 1} & \multicolumn{3}{|c|}{ Model 2} & \multicolumn{3}{|c|}{ Model 3} \\
\hline & $B$ & $S E$ & $\beta$ & $B$ & $S E$ & $\beta$ & $B$ & $S E$ & $\beta$ \\
\hline (Constant) & $2.49^{* * *}$ & 0.15 & & $1.05^{* * *}$ & 0.17 & 0.17 & $0.65^{* * *}$ & 0.15 & 0.15 \\
\hline Female & 0.01 & 0.05 & 0.00 & -0.04 & 0.05 & -0.02 & -0.03 & 0.04 & -0.02 \\
\hline Age & $-0.14^{* * *}$ & 0.02 & -0.27 & $-0.12^{* * *}$ & 0.02 & -0.23 & $-0.06^{* * *}$ & 0.02 & -0.12 \\
\hline Education & 0.05 & 0.04 & 0.04 & 0.02 & 0.04 & 0.02 & -0.02 & 0.03 & -0.02 \\
\hline European NZ & $-0.25^{* *}$ & 0.08 & -0.14 & $-0.16^{*}$ & 0.07 & -0.09 & -0.10 & 0.06 & -0.06 \\
\hline Māori & 0.03 & 0.09 & 0.01 & 0.03 & 0.08 & 0.02 & 0.06 & 0.07 & 0.02 \\
\hline Pasifika & 0.11 & 0.11 & 0.04 & $0.14^{*}$ & 0.10 & 0.04 & 0.14 & 0.09 & 0.04 \\
\hline Ideology & 0.03 & 0.03 & 0.03 & 0.00 & 0.02 & 0.00 & -0.01 & 0.02 & -0.01 \\
\hline Income & -0.03 & 0.02 & -0.07 & -0.02 & 0.02 & -0.05 & -0.02 & 0.01 & -0.05 \\
\hline Employed & -0.05 & 0.06 & -0.03 & 0.03 & 0.05 & 0.02 & 0.03 & 0.05 & 0.02 \\
\hline Has children & 0.04 & 0.06 & 0.02 & 0.04 & 0.05 & 0.02 & 0.07 & 0.05 & 0.04 \\
\hline Marital status & 0.08 & 0.06 & 0.05 & 0.07 & 0.05 & 0.04 & 0.06 & 0.04 & 0.04 \\
\hline Group membership & 0.16 & 0.05 & 0.09 & 0.19 & 0.05 & 0.11 & 0.10 & 0.04 & 0.06 \\
\hline Smoking status & 0.05 & 0.06 & 0.03 & 0.05 & 0.05 & 0.03 & 0.00 & 0.05 & 0.00 \\
\hline \multicolumn{4}{|c|}{$\begin{array}{l}\text { Co-benefits: environmental protection } \\
\text { on coronavirus response }\end{array}$} & $0.49^{* * *}$ & 0.04 & 0.45 & $0.33^{* * *}$ & 0.03 & 0.30 \\
\hline \multicolumn{4}{|c|}{$\begin{array}{l}\text { Co-impacts: extreme weather events } \\
\text { on coronavirus response }\end{array}$} & 0.01 & 0.04 & 0.01 & -0.04 & 0.04 & -0.04 \\
\hline \multicolumn{4}{|l|}{ Collective efficacy } & & & & $0.35^{* * *}$ & 0.02 & 0.45 \\
\hline$\Delta R^{2}$ & \multicolumn{3}{|l|}{$.12^{* * *}$} & \multicolumn{3}{|l|}{$.31^{* * *}$} & \multicolumn{3}{|l|}{$.46^{* * *}$} \\
\hline F Change & \multicolumn{3}{|l|}{12.48} & \multicolumn{3}{|l|}{138.13} & \multicolumn{3}{|l|}{290.51} \\
\hline
\end{tabular}

Note: $n=1032 .{ }^{* * *} p<.001,{ }^{* *} p<.01,{ }^{*} p<.05$. Gender was measured dichotomously compared male with female (1). The three ethnicity variables were dummy coded with Asian and other ethnicities coded as a reference category. Employed were coded as 1 for respondents who said they are currently employed compared to others. Parental status was coded as 1 with reference to others (0). Marital status was coded for respondents with a spouse, partner, de-facto, live-in relationship to others. Group membership was coded for respondents who said they belonged to a local club with reference to others. Respondents who smoked, rolled their own cigarettes, or vaped were coded with reference to others.

While perceptions about co-impacts of extreme weather events on coronavirus response was positively associated with support for clean and green COVID-19 economic recovery policies $(\beta=.08, p<.05)$, with the addition of collective efficacy in the model, the $\mathrm{H} 2 \mathrm{a}$ was not supported $(\beta=.04, p=.22)$. No support was found for $\mathrm{H} 2 \mathrm{~b}$ as perceptions about co-impacts was not significantly associated with political engagement on climate change $(\beta=-.04, p=.23)$.

Support was found for both $\mathrm{H} 3 \mathrm{a}$ and $\mathrm{H} 3 \mathrm{~b}$ : perceived collective efficacy was positively associated with support for clean and green COVID-19 economic recovery policies $(\beta=.44, p<.001)$ and political engagement $(\beta=.45, p<.001)$.

The hypothesized mediation, H4a, was partly supported. Perceived collective efficacy partly mediated the association between perceptions about co-benefits with support for clean and green COVID-19 economic recovery policies (indirect effect $=.21$, bootstrapped confidence interval .17 to .25 ) (see Figure 1). An alternative model, with perceptions about co-benefits mediating the association between collective efficacy and policy support was also supported (indirect 


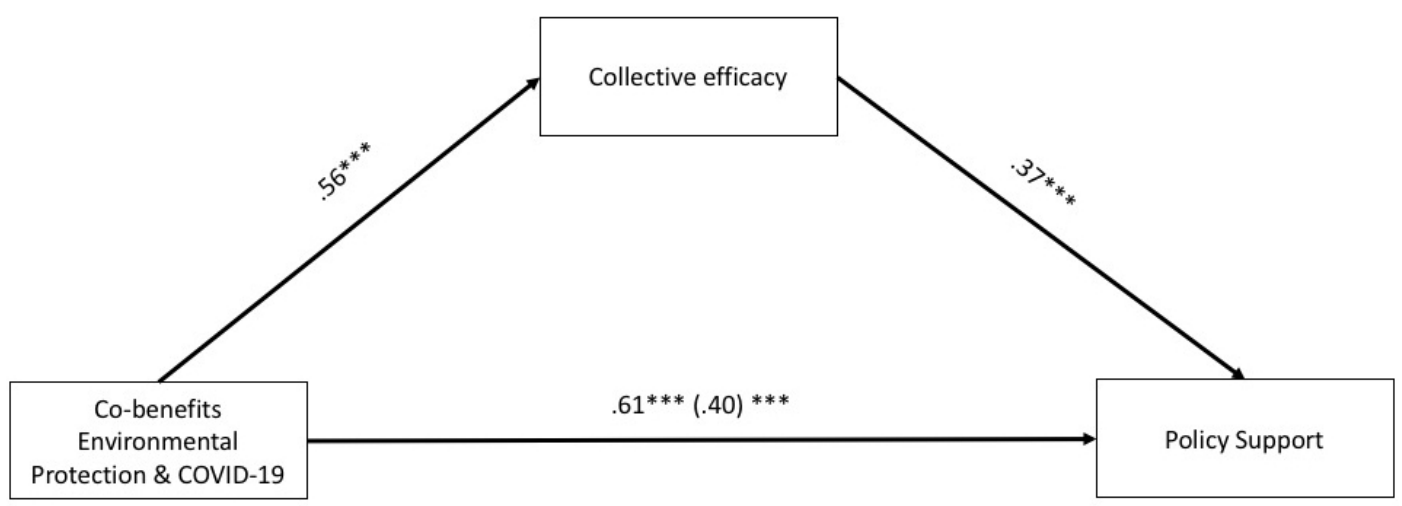

Note: Results of the PROCESS mediation analysis. The reported path values are unstandardized regression coefficients. The direct effect of co-benefits after including the collective efficacy mediator are in the parenthesis. All demographic variables were entered in the model as co-variates.

Figure 1. Mediation analysis with perceived collective efficacy as mediator between perceived co-benefits and policy support.

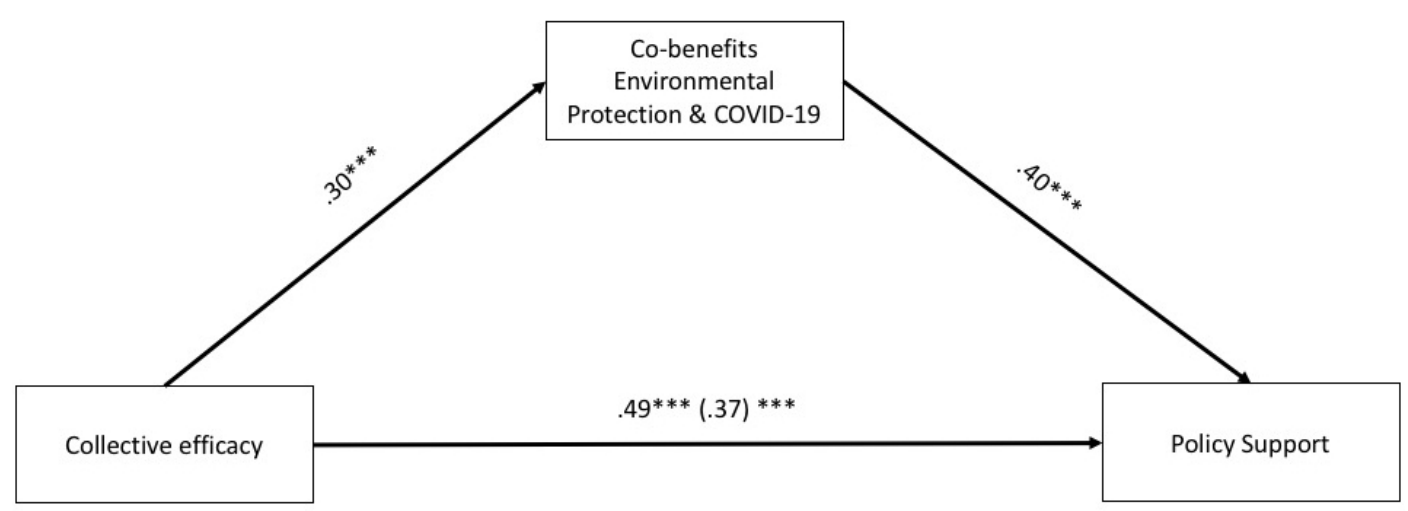

Note: Results of the alternative PROCESS mediation analysis. The reported path values are unstandardized regression coefficients. The direct effect of collective efficacy after including the mediator are in the parenthesis. All demographic variables were entered in the model as co-variates.

Figure 2. Mediation analysis with perceived co-benefits as mediator between perceived collective efficacy and policy support.

effect $=.12$, bootstrapped confidence interval .10 to .15 ) (see Figure 2), indicating a mutual influence of perception about perceived co-benefits and collective efficacy in shaping policy support.

The second hypothesized mediation, H4b, was also partly supported. Perceived collective efficacy partly mediated the association between perceptions about co-impacts with policy support (indirect effect $=.19$, bootstrapped confidence interval .15 to .24) (see Figure 3). An alternative model, with perceptions about co-impacts mediating the association between collective efficacy and policy support was also supported (indirect effect $=.06$, bootstrapped confidence interval .04 to .09), indicating a mutual influence of perception about perceived co-benefits and collective efficacy in shaping policy support (see Figure 4).

Support was found for H5. Councils with higher levels of community collective efficacy were more likely to declare climate emergency $(M=2.76, S D=.13)$ than 


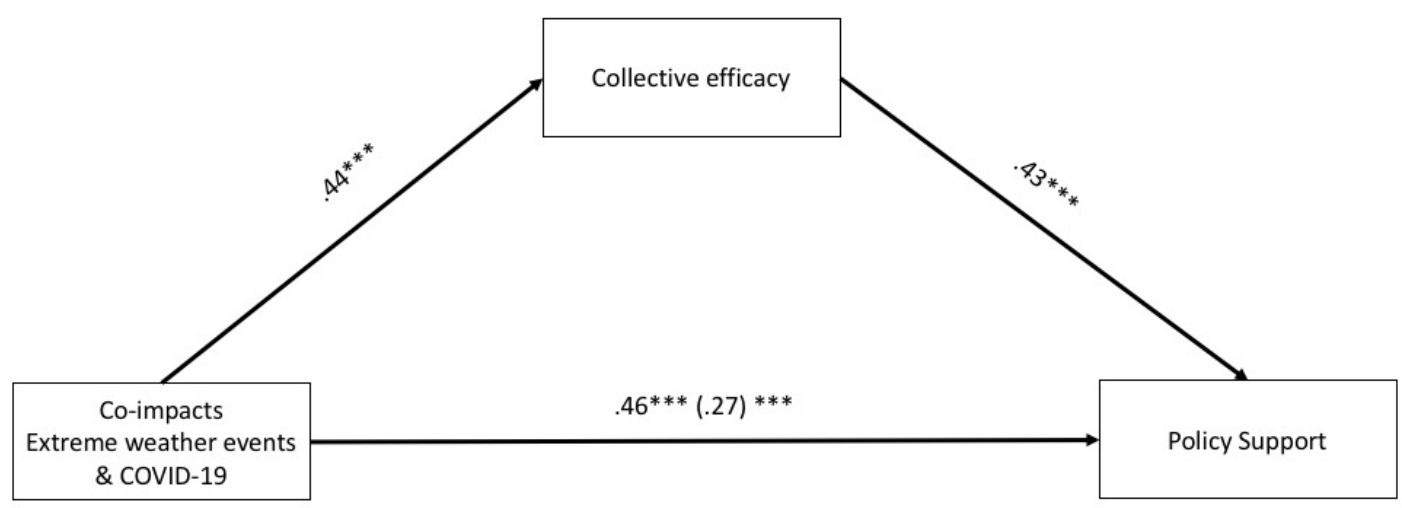

Note: Results of the PROCESS mediation analysis. The reported path values are unstandardized regression coefficients. The direct effect of co-benefits after including the collective efficacy mediator are in the parenthesis. All demographic variables were entered in the model as co-variates.

Figure 3. Mediation analysis with perceived collective efficacy as mediator between perceived co-impacts and policy support.

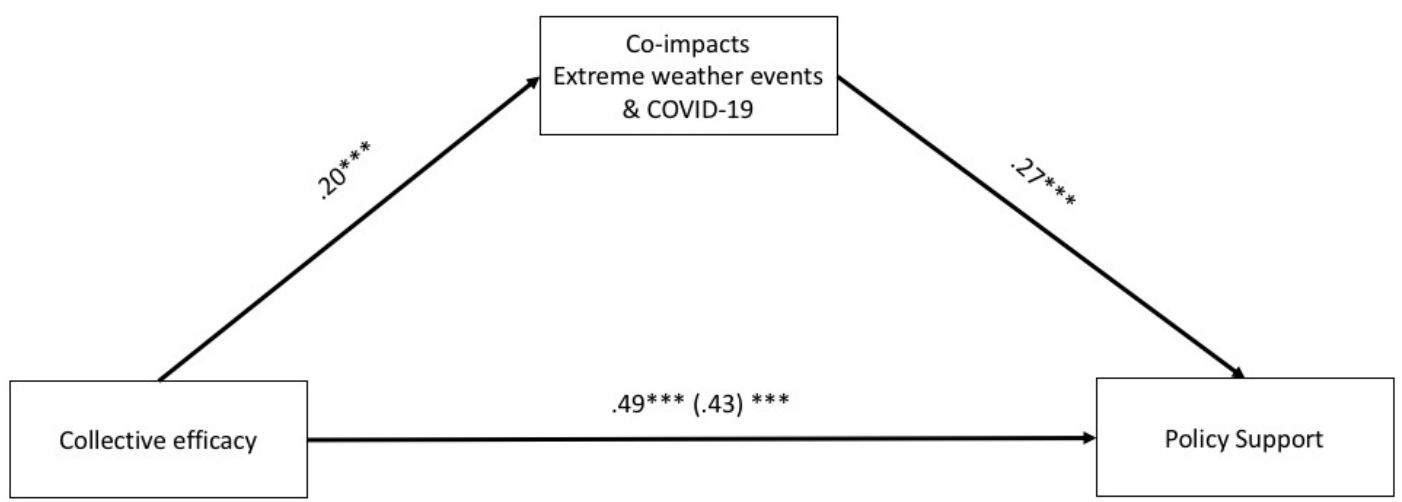

Note: Results of the alternative PROCESS mediation analysis. The reported path values are unstandardized regression coefficients. The direct effect of co-benefits after including the mediator are in the parenthesis. All demographic variables were entered in the model as co-variates.

Figure 4. Mediation analysis with perceived co-impacts as mediator between perceived collective efficacy and policy support.

councils with lower levels of community collective efficacy $(M=2.71, S D=.21)$, $t(1008)=-4.472, p<0.001$.

\section{Discussion}

Similar to U.S. and other developed countries [Fagan and Huang, 2020], New Zealand public is also divided on climate change along partisan lines [Linde, 2020; Milfont et al., 2015]. Reframing climate change in ways that aligns with public concerns about health, economy, and society can potentially dissolve the partisan divide on climate change action. Yet, empirical evidence provides mixed results to the impact of communicating co-benefits in instigating public commitment for climate change action [e.g., Bain et al., 2016; Bernauer and McGrath, 2016; Feldman and Hart, 2018; Li and Su, 2018]. Moreover, limited research has been conducted to understand a mechanism through which framing climate co-benefits would increase mitigation behaviors [Nabi, Gustafson and Jensen, 2018]. 
This study found that public perceptions about co-benefits of actions to address environmental protection that also protects against infectious disease outbreaks such as the coronavirus is associated with policy support, partly through perceived collective efficacy. In addition, the association between co-impacts of extreme weather events on coronavirus response and policy support was partly mediated through perceived collective efficacy. The regression models explained about half the variance in policy support and political engagement.

The positive association between perceptions about co-benefits of actions to address environmental protection and COVID-19 with policy support and political engagement is aligned with previous studies [Amelung et al., 2019; Bain et al., 2016; Myers et al., 2012; Walker, Kurz and Russel, 2018]. This finding is notable as several previous studies have either experimentally manipulated the co-benefits frames [e.g., Bernauer and McGrath, 2016; Hart and Feldman, 2018; Nabi, Gustafson and Jensen, 2018; Singh and Swanson, 2017; Walker, Kurz and Russel, 2018] or asked respondents to imagine a future when mitigation actions are successful [Bain et al., 2016]. This study directly assessed public perceptions about the co-benefits, adding to the robustness of findings from a diversity of methodologies. In contrast to mixed findings from previous studies, this study not only shows that individuals' perceive co-benefits of climate-related actions on health but that such perceptions are significantly associated with policy support and political engagement. It is possible that these directly assessed beliefs about co-benefits of climate action on health are likely to reflect attitude certainty and may persist over time, a topic for future research.

However, limited support was found about perceived co-impacts of extreme weather events on COVID-19 response with policy support and political engagement, respectively. While such co-impact perceptions were associated with the policy support (and not with political engagement), their significance dwindled in the presence of collective efficacy. It is possible that the public has not made a connection or that the connection has not reached a sufficient threshold in New Zealand. The U.S. faced multiple extreme weather event disasters during the on-going pandemic, including, hurricanes, tornadoes, and wildfires, resulting in over 150 deaths and 22 billion-dollar loss [National Oceanic and Atmospheric Administration, 2021]. New Zealand has not experienced an extreme weather event disaster on a similar scale during the COVID-19 pandemic, however. These extreme weather events have impacted coronavirus response: "proven standard disaster mitigation strategies - mass sheltering and population evacuation increase the risk of viral transmission by moving large groups of people and gathering them close together" [Salas, Shultz and Solomon, 2020, para. 3]. Future research should test these associations in other countries, particularly where extreme weather events are recent and likely salient in the public mind.

Public understanding of climate change is a constellation of individuals' experience, perceptions, and beliefs. While several researchers have focused on directly assessing beliefs related to climate change, lack of public and policy enthusiasm has led scholars to test if communicating climate change along with other issues, such as health and environment, that the public considers more relevant and important results in productive engagement. Public health appears to be an important anchor through which to induce public attention to an abstract and global issue of climate change [Walker, Kurz and Russel, 2018]. Perceptions about 
co-benefits of climate change actions likely increases public belief that addressing climate change is important as it aligns with their priorities. Indeed, Bain et al. [2016] argued that communicating co-benefits to societal concerns may be more important to promote public activism on climate change than communicating importance of climate change. Further, such perceptions that two issues can be resolved with one policy likely increases their efficacy beliefs. Understanding co-benefits for climate action can increase efficacy beliefs about benefits of co-joint efforts. Public understanding therefore can be enhanced by seeking to make these co-benefits, when scientifically appropriate, explicit in the public mind.

The most important finding of this study is that perceived collective efficacy is not only significantly associated with climate change engagement - through mitigation policy support and political engagement - but that it also partly mediates the association between perceived co-benefit and co-impact frames and climate change actions. Previous studies have largely focused on emotions [e.g., Nabi, Gustafson and Jensen, 2018], issue salience, and personal impact [Amelung et al., 2019; Walker, Kurz and Russel, 2018] as a mediator between co-benefit frames and climate action. While emotions can play an important role in shaping public action, it is possible that emotions are affected by and in turn affect perceptions of efficacy, which is a proximal influence on behavior [e.g., Bandura, 2000]. Future research should test how perceptions about co-benefits, emotions, and efficacy perceptions shape citizens collective action efforts on climate change.

It is important to note that the primary aim of the study was not to find a causal pathway, but to identify a mechanism through which co-benefits frames can instigate climate action - an area largely unexplored. Alternative mediation models tested in this study indicate that both collective efficacy and co-benefits perceptions shape policy support, although the effect size is stronger with collective efficacy as a mediator between co-benefits and climate action. Future research should test these implications through experimental exposure, manipulating both information about co-benefits and collective efficacy, and manipulating the sequence of these constructs, in shaping pro-environmental behaviors.

There exists an active scholarly debate on whether climate change messaging, particularly among the skeptic publics, should altogether refrain from using 'climate change', to achieve the same mitigation goals: "when discussing climate change solutions that have non-climate change related co-benefits, it may be more effective to not mention climate change, especially when communicating with Republicans" [Hart and Feldman, 2018, p. 7]. However, Petrovic, Madrigano and Zaval [2014] found that even if climate change is not mentioned, discussing air pollution in terms of fossil fuels trigger political polarization, partly due to pre-existing schemas of associating fossil fuels with climate change. In a second framing study, Petrovic, Madrigano and Zaval [2014] removed any mention of fossil fuels and instead emphasized health benefits ("air pollution contains gases and particulates that are harmful to human health, and will lead to many premature deaths") compared to climate change benefits ("air pollution contains gases and particulates that contribute to climate change, and will lead to negative environmental consequences"). They found that while conservatives were more likely to agree with the health impact statement and were more willing to support national policies to address air pollution, the opposite was true for liberals (that is climate change was a stronger motivator than a health frame). 
In other words, re-packing climate change mitigation without reference to climate change may gain new publics but may dampen support from already highly involved and motivated public. It is also important to note that these studies were conducted in a highly polarized milieu of U.S. [Fagan and Huang, 2020], with its own history of strong partisan differences not just in climate change but also in many societal issues. The applicability of such findings in other countries are important to be replicated instead of relying on studies based only in the U.S. The findings of this study suggest that non-climate frames - environmental protection and extreme weather events - may act as a rising tide that lifts all boats.

Further, addressing a limitation in several studies that use self-reports, this study found that heightened sense of community collective efficacy matter in shaping action in local communities. Local councils with higher levels of community collective efficacy were more likely to declare climate emergency. This connection between community members perceptions and local governmental action on climate change further testifies the importance of not only informing people about the co-benefits about climate action, but increasing their efficacy beliefs that coordinated action can and does result in policy change, at least at the local government level.

\section{Limitations}

Due to the cross-section nature of the data, casualty is not assumed, and the ordering of the relationships should be better tested using experimental designs. Even though several studies apply mediation analysis to survey data to explore the presumed influence as hypothesized by well-tested theories [e.g., Lull et al., 2020], experimental manipulation and longitudinal designs can better help identify how and why co-benefit frames shape public understanding and engagement with climate change. It is also important to note experimental research have found small to medium effects of co-benefits frames on public action [Feldman and Hart, 2018; $\mathrm{Li}$ and $\mathrm{Su}, 2018$ ]. Equally important is to note that citizens are already exposed to a variety of competing claims through media, thereby potentially limiting the framing effects as generally hypothesized in experimental research [Bernauer and McGrath, 2016]. Finally, while we looked at collective efficacy as the mediator, previous research has identified additional important mediators such as emotions [Nabi, Gustafson and Jensen, 2018] and message relevance [Walker, Kurz and Russel, 2018], suggesting a need for more comprehensive models to understand the use and impact of co-benefit frames. Future research can examine the optimal level of co-benefits mentions as some studies show that subtle mentions are more likely to have higher resonance [Walker, Kurz and Russel, 2018]. The association between community collective efficacy and local council climate emergency declaration both community-level variables - are better tested through newer methodologies that are still being tested as both individual-level analysis or aggregate analysis can provide biased results [Foster-Johnson and Kromrey, 2018].

\section{Conclusion}

Despite increasing scientific consensus on health impacts of climate change, few studies focus if the public understands these health impacts, and if perceptions about co-benefits of actions to address climate and health are associated with 
increased public engagement with climate change. Findings of this study show that public perceptions about co-benefits are associated with support for climate-friendly COVID-19 economic recovery policies and with political activism on climate change. Moreover, the association between perceptions about co-benefits and policy support is partly mediated through perceived collective efficacy. Individual-level collective efficacy is not only associated with self-reports of policy support and political activism, but that community-level collective efficacy can potentially shape local government policies. Communication about potential co-benefits of climate and health policies and messages that heighten collective efficacy are likely to shape climate activism and help enact policy change.

\section{References}

Akerlof, K. L., Boules, C., Ban Rohring, E., Rohring, B. and Kappalman, S. (2020). 'Governmental communication of climate change risk and efficacy: moving audiences toward "danger control"'. Environmental Management 65 (5), pp. 678-688. https://doi.org/10.1007/s00267-020-01283-8.

Amelung, D., Fischer, H., Herrmann, A., Aall, C., Louis, V. R., Becher, H., Wilkinson, P. and Sauerborn, R. (2019). 'Human health as a motivator for climate change mitigation: results from four European high-income countries'. Global Environmental Change 57, 101918. https://doi.org/10.1016/j.gloenvcha.2019.05.002.

Anderson, B., Böhmelt, T. and Ward, H. (2017). 'Public opinion and environmental policy output: a cross-national analysis of energy policies in Europe'. Environmental Research Letters 12 (11), 114011. https://doi.org/10.1088/1748-9326/aa8f80.

Bain, P. G., Milfont, T. L., Kashima, Y., Bilewicz, M., Doron, G., Garðarsdóttir, R. B., Gouveia, V. V., Guan, Y., Johansson, L.-O., Pasquali, C., Corral-Verdugo, V., Aragones, J. I., Utsugi, A., Demarque, C., Otto, S., Park, J., Soland, M., Steg, L., González, R., Lebedeva, N., Madsen, O. J., Wagner, C., Akotia, C. S., Kurz, T., Saiz, J. L., Schultz, P. W., Einarsdóttir, G. and Saviolidis, N. M. (2016). 'Co-benefits of addressing climate change can motivate action around the world'. Nature Climate Change 6 (2), pp. 154-157. https://doi.org/10.1038/nclimate2814.

Bandura, A. (1998). 'Health promotion from the perspective of social cognitive theory'. Psychology \& Health 13 (4), pp. 623-649. https://doi.org/10.1080/08870449808407422.

- (2000). 'Exercise of human agency through collective efficacy'. Current Directions in Psychological Science 9 (3), pp. 75-78. https://doi.org/10.1111/1467-8721.00064.

- (2001). 'Social cognitive theory of mass communication'. Media Psychology 3 (3), pp. 265-299. https://doi.org/10.1207/s1532785xmep0303_03.

Bernauer, T. and McGrath, L. F. (2016). 'Simple reframing unlikely to boost public support for climate policy'. Nature Climate Change 6 (7), pp. 680-683. https://doi.org/10.1038/nclimate2948.

Bostrom, A., Hayes, A. L. and Crosman, K. M. (2019). 'Efficacy, action, and support for reducing climate change risks'. Risk Analysis 39 (4), pp. 805-828. https://doi.org/10.1111/risa.13210. 
Brancalion, P. H. S., Broadbent, E. N., de-Miguel, S., Cardil, A., Rosa, M. R., Almeida, C. T., Almeida, D. R. A., Chakravarty, S., Zhou, M., Gamarra, J. G. P., Liang, J., Crouzeilles, R., Hérault, B., Aragão, L. E. O. C., Silva, C. A. and Almeyda-Zambrano, A. M. (2020). 'Emerging threats linking tropical deforestation and the COVID-19 pandemic'. Perspectives in Ecology and Conservation 18 (4), pp. 243-246.

https://doi.org/10.1016/j.pecon.2020.09.006.

Centers for Disease Control and Prevention (23rd June 2021). Natural disasters, severe weather, and COVID-19. URL: https://www.cdc.gov/disasters/covid-19 /disasters_severe_weather_and_covid-19.html.

Chalasani, R. (22nd April 2020). 'Photos: wildlife roams during the coronavirus pandemic'. ABC News. URL: https://abcnews.go.com/International/photos -wildlife-roams-planets-human-population-isolates/story?id=70213431 (visited on 7th October 2020).

Chen, M.-F. (2015). 'Self-efficacy or collective efficacy within the cognitive theory of stress model: which more effectively explains people's self-reported proenvironmental behavior?' Journal of Environmental Psychology 42, pp. 66-75. https://doi.org/10.1016/j.jenvp.2015.02.002.

Chong, D. and Druckman, J. N. (2007). 'A theory of framing and opinion formation in competitive elite environments'. Journal of Communication 57 (1), pp. 99-118. https://doi.org/10.1111/j.1460-2466.2006.00331.x.

Controller and Auditor-General (2020). Insights into local government: 2019. Wellington, New Zealand: Office of the Auditor-General. URL: https://oag.parliament.nz/2020/local-govt/docs/local-govt.pdf.

Entman, R. M. (2002). 'Framing: towards clarification of a fractured paradigm'. In: McQuail's reader in mass communication theory. Ed. by D. McQuail. London. U.K.: SAGE Publications, pp. 390-397.

Fagan, M. and Huang, C. (16th October 2020). 'Many globally are as concerned about climate change as about the spread of infectious diseases'. Pew Research Center. URL: https://www . pewresearch.org/fact-tank/2020/10/16/many-glo bally-are-as-concerned-about-climate-change-as-about-the-spread-ofinfectious-diseases/ (visited on 1st December 2020).

Feldman, L. and Hart, P. S. (2018). 'Broadening exposure to climate change news? How framing and political orientation interact to influence selective exposure'. Journal of Communication 68 (3), pp. 503-524. https://doi.org/10.1093/joc/jqy011.

Foster-Johnson, L. and Kromrey, J. D. (2018). 'Predicting group-level outcome variables: an empirical comparison of analysis strategies'. Behavior Research Methods 50 (6), pp. 2461-2479. https://doi .org/10.3758/s13428-018-1025-8.

Gettleman, J. and Conway, R. (8th April 2020). 'India savors a rare upside to coronavirus: clean air'. The New York Times. URL: https: //www nytimes . com/20 20/04/08/world/asia/india-pollution-coronavirus.html.

Goddard, R. D., Hoy, W. K. and Hoy, A. W. (2004). 'Collective efficacy beliefs: theoretical developments, empirical evidence, and future directions'. Educational Researcher 33 (3), pp. 3-13. https://doi.org/10.3102/0013189x033003003.

Gromet, D. M., Kunreuther, H. and Larrick, R. P. (2013). ‘Political ideology affects energy-efficiency attitudes and choices'. Proceedings of the National Academy of Sciences 110 (23), pp. 9314-9319. https://doi.org/10.1073/pnas.1218453110. 
Hart, P. S. and Feldman, L. (2016). 'The influence of climate change efficacy messages and efficacy beliefs on intended political participation'. PLOS ONE 11 (8), e0157658. https://doi .org/10.1371/journal . pone.0157658.

- (2018). 'Would it be better to not talk about climate change? The impact of climate change and air pollution frames on support for regulating power plant emissions'. Journal of Environmental Psychology 60, pp. 1-8. https://doi.org/10.1016/j.jenvp.2018.08.013.

Hayes, A. F. (2013). Introduction to mediation, moderation, and conditional process analysis: a regression-based approach. New York, NY, U.S.A.: Guilford Press.

Hepburn, C., O'Callaghan, B., Stern, N., Stiglitz, J. and Zenghelis, D. (2020). 'Will COVID-19 fiscal recovery packages accelerate or retard progress on climate change?' Oxford Review of Economic Policy 36 (Supplement_1), S359-S381. https://doi.org/10.1093/oxrep/graa015.

Keesing, F., Belden, L. K., Daszak, P., Dobson, A., Harvell, C. D., Holt, R. D., Hudson, P., Jolles, A., Jones, K. E., Mitchell, C. E., Myers, S. S., Bogich, T. and Ostfeld, R. S. (2010). 'Impacts of biodiversity on the emergence and transmission of infectious diseases'. Nature 468 (7324), pp. 647-652. https://doi.org/10.1038/nature09575.

Kreslake, J. M., Sarfaty, M., Roser-Renouf, C., Leiserowitz, A. A. and Maibach, E. W. (2018). 'The critical roles of health professionals in climate change prevention and preparedness'. American Journal of Public Health 108 (S2), S68-S69. https://doi.org/10.2105/ajph.2017.304044.

Lauren, N., Fielding, K. S., Smith, L. and Louis, W. R. (2016). 'You did, so you can and you will: self-efficacy as a mediator of spillover from easy to more difficult pro-environmental behaviour'. Journal of Environmental Psychology 48, pp. 191-199. https://doi.org/10.1016/j.jenvp.2016.10.004.

Lee, F. L. F. (2006). 'Collective efficacy, support for democratization, and political participation in Hong Kong'. International Journal of Public Opinion Research 18 (3), pp. 297-317. https://doi.org/10.1093/ijpor/edh105.

Leiserowitz, A., Maibach, E., Rosenthal, S., Kotcher, J., Ballew, M., Bergquist, P., Gustafson, A., Goldberg, M. and Wang, X. (2020). Politics E global warming. April 2020. New Haven, CT, U.S.A.: Yale University and George Mason University. URL: https://climatecommunication.yale.edu/publications/po litics-global-warming-april-2020/.

Leiserowitz, A., Maibach, E., Rosenthal, S., Kotcher, J., Bergquist, P., Gustafson, A., Ballew, M. and Goldberg, M. (2019). Climate activism: beliefs, attitudes, and behaviors. November 2019. New Haven, CT, U.S.A.: Yale University and George Mason University. URL: https://climatecommunication.yale.edu/publicati ons/climate-activism-beliefs-attitudes-and-behaviors-november-2019/.

Li, N. and Su, L. Y.-F. (2018). 'Message framing and climate change communication: a meta-analytical review'. Journal of Applied Communications 102 (3), 4. https://doi.org/10.4148/1051-0834.2189.

Linde, S. (2020). 'The politicization of risk: party cues, polarization, and public perceptions of climate change risk'. Risk Analysis 40 (10), pp. 2002-2018. https://doi.org/10.1111/risa.13530.

Lull, R. B., Akin, H., Hallman, W. K., Brossard, D. and Jamieson, K. H. (2020). 'Modeling risk perceptions, benefit perceptions, and approval of releasing genetically engineered mosquitoes as a response to Zika virus'. Environmental Communication 14 (7), pp. 933-953.

https://doi.org/10.1080/17524032.2019.1685558. 
Maibach, E. W., Nisbet, M., Baldwin, P., Akerlof, K. and Diao, G. (2010). 'Reframing climate change as a public health issue: an exploratory study of public reactions'. BMC Public Health 10, 299.

https://doi.org/10.1186/1471-2458-10-299.

McCright, A. M. and Dunlap, R. E. (2011). 'The politicization of climate change and polarization in the American public's views of global warming, 2001-2010'. The Sociological Quarterly 52 (2), pp. 155-194. https://doi.org/10.1111/j.1533-8525.2011.01198.x.

Milfont, T. L. (2012). 'The interplay between knowledge, perceived efficacy, and concern about global warming and climate change: a one-year longitudinal study'. Risk Analysis 32 (6), pp. 1003-1020. https://doi.org/10.1111/j.1539-6924.2012.01800.x.

Milfont, T. L., Milojev, P., Greaves, L. M. and Sibley, C. G. (2015). 'Socio-structural and psychological foundations of climate change beliefs'. New Zealand Journal of Psychology 44 (1), pp. 17-30.

Morton, J. (28th July 2020). 'Covid-19 leaves more Kiwis worried about climate change - poll'. NZ Herald.

URL: https://www.nzherald.co.nz/nz/covid-19-leaves-more-kiwis-worrie d-about-climate-change-poll/7TLZPUKKLRVHYBAZXPZGQFPFUI/ (visited on 9th October 2020).

Morton, T. A., Rabinovich, A., Marshall, D. and Bretschneider, P. (2011). 'The future that may (or may not) come: how framing changes responses to uncertainty in climate change communications'. Global Environmental Change 21 (1), pp. 103-109. https://doi.org/10.1016/j.gloenvcha.2010.09.013.

Myers, T. A., Nisbet, M. C., Maibach, E. W. and Leiserowitz, A. A. (2012). 'A public health frame arouses hopeful emotions about climate change'. Climatic Change 113 (3-4), pp. 1105-1112. https://doi.org/10.1007/s10584-012-0513-6.

Nabi, R. L., Gustafson, A. and Jensen, R. (2018). 'Framing climate change: exploring the role of emotion in generating advocacy behavior'. Science Communication 40 (4), pp. 442-468. https : //doi .org/10.1177/1075547018776019.

National Oceanic and Atmospheric Administration (8th January 2021). 'Record number of billion-dollar disasters struck U.S. in 2020'.

URL: https://www.noaa.gov/stories/record-number-of-billion-dollar-di sasters-struck-us-in-2020 (visited on 17th June 2021).

Nisbet, M. C. (2009). 'Communicating climate change: why frames matter for public engagement'. Environment: Science and Policy for Sustainable Development 51 (2), pp. 12-23. https://doi.org/10.3200/envt.51.2.12-23.

Ostrom, E. (2010). 'A multi-scale approach to coping with climate change and other collective action problems'. Solutions 1 (2), pp. 27-36.

URL: http: //hdl. handle. net/10535/5774.

Petrovic, N., Madrigano, J. and Zaval, L. (2014). 'Motivating mitigation: when health matters more than climate change'. Climatic Change 126 (1-2), pp. 245-254. https://doi.org/10.1007/s10584-014-1192-2.

Poushter, J. and Huang, C. (9th September 2020). 'Despite pandemic, many Europeans still see climate change as greatest threat to their countries'. Pew Research Center. URL: https: //www . pewresearch .org/global/2020/09/09 /despite-pandemic-many-europeans-still-see-climate-change-as-greate st-threat-to-their-countries/ (visited on 9th October 2020). 
Pozzer, A., Dominici, F., Haines, A., Witt, C., Münzel, T. and Lelieveld, J. (2020). 'Regional and global contributions of air pollution to risk of death from COVID-19'. Cardiovascular Research 116 (14), pp. 2247-2253.

https://doi.org/10.1093/cvr/cvaa288.

Price, V. and Tewksbury, D. (1997). 'News values and public opinion: a theoretical account of media priming and framing'. In: Progress in communication sciences: advances in persuasion. Ed. by G. A. Barnett and F. J. Boster. Vol. 13. New York, NY, U.S.A.: Ablex Publishing Corporation, pp. 173-212.

Roser-Renouf, C., Atkinson, L., Maibach, E. and Leiserowitz, A. (2016). 'The consumer as climate activist'. International Journal of Communication 10, pp. 4759-4783.

Roser-Renouf, C., Maibach, E. W., Leiserowitz, A. and Zhao, X. (2014). 'The genesis of climate change activism: from key beliefs to political action'. Climatic Change 125 (2), pp. 163-178. https://doi.org/10.1007/s10584-014-1173-5.

Salas, R. N., Shultz, J. M. and Solomon, C. G. (2020). 'The climate crisis and Covid-19 - A major threat to the pandemic response'. The New England Journal of Medicine 383 (11), e70. https://doi . org/10.1056/NEJMp2022011.

Scheufele, D. A. (1999). 'Framing as a theory of media effects'. Journal of Communication 49 (1), pp. 103-122. https://doi.org/10.1111/j.1460-2466.1999.tb02784.x.

Semenza, J. C., Rocklöv, J., Penttinen, P. and Lindgren, E. (2016). ‘Observed and projected drivers of emerging infectious diseases in Europe'. Annals of the New York Academy of Sciences 1382 (1), pp. 73-83. https://doi.org/10.1111/nyas.13132.

Singh, S. P. and Swanson, M. (2017). 'How issue frames shape beliefs about the importance of climate change policy across ideological and partisan groups'. PLoS ONE 12 (7), e0181401. https://doi .org/10.1371/journal . pone. 0181401.

Spence, A., Poortinga, W., Butler, C. and Pidgeon, N. F. (2011). 'Perceptions of climate change and willingness to save energy related to flood experience'. Nature Climate Change 1 (1), pp. 46-49. https://doi.org/10.1038/nclimate1059.

Suk, J. E., Vaughan, E. C., Cook, R. G. and Semenza, J. C. (2020). ‘Natural disasters and infectious disease in Europe: a literature review to identify cascading risk pathways'. European Journal of Public Health 30 (5), pp. 928-935. https://doi.org/10.1093/eurpub/ckz111.

Thaker, J., Maibach, E., Leiserowitz, A., Zhao, X. and Howe, P. (2016). 'The role of collective efficacy in climate change adaptation in India'. Weather, Climate, and Society 8 (1), pp. 21-34. https://doi .org/10.1175/WCAS-D-14-00037.1.

Velasquez, A. and LaRose, R. (2015). 'Youth collective activism through social media: the role of collective efficacy'. New Media \& Society 17 (6), pp. 899-918. https://doi.org/10.1177/1461444813518391.

Walker, B. J. A., Kurz, T. and Russel, D. (2018). 'Towards an understanding of when non-climate frames can generate public support for climate change policy'. Environment and Behavior 50 (7), pp. 781-806. https://doi.org/10.1177/0013916517713299. 
Watts, N., Adger, W. N., Agnolucci, P., Blackstock, J., Byass, P., Cai, W., Chaytor, S., Colbourn, T., Collins, M., Cooper, A., Cox, P. M., Depledge, J., Drummond, P., Ekins, P., Galaz, V., Grace, D., Graham, H., Grubb, M., Haines, A., Hamilton, I., Hunter, A., Jiang, X., Li, M., Kelman, I., Liang, L., Lott, M., Lowe, R., Luo, Y., Mace, G., Maslin, M., Nilsson, M., Oreszczyn, T., Pye, S., Quinn, T., Svensdotter, M., Venevsky, S., Warner, K., Xu, B., Yang, J., Yin, Y., Yu, C., Zhang, Q., Gong, P., Montgomery, H. and Costello, A. (2015). 'Health and climate change: policy responses to protect public health'. The Lancet 386 (10006), pp. 1861-1914. https://doi .org/10.1016/s0140-6736(15)60854-6.

Witte, K. (1992). 'Putting the fear back into fear appeals: the extended parallel process model'. Communication Monographs 59 (4), pp. 329-349. https://doi.org/10.1080/03637759209376276.

World Health Organization (22nd April 2020). Coronavirus disease (COVID-19): climate change. URL: https://www. who. int/westernpacific/news/q-a-detail /q-a-on-climate-change-and-covid-19 (visited on 6th October 2020).

- (30th March 2021). Origins of the SARS-CoV-2 virus. URL: https : / www . who . int /health-topics/coronavirus/origins-of-the-virus (visited on 16th June 2021).

Authors

Dr. Jagadish Thaker is a Senior Lecturer at Massey University. His research areas focus on climate change, science, and health communication. He was an Associate Editor of the 3-volume Oxford Encyclopaedia of Climate Change Communication. E-mail: jthaker@massey.ac.nz.

Dr. Brian Floyd is a Lecturer at Massey University. His research examines ways to increase public and policy engagement on climate change.

E-mail: brianfloydresearch@gmail.com.

How to cite

Thaker, J. and Floyd, B. (2021). 'Co-benefits associated with public support for climate-friendly COVID-19 recovery policies and political activism'. JCOM 20 (05), A08. https:/ / doi.org/10.22323/2.20050208.

(C) The Author(s). This article is licensed under the terms of the Creative Commons Attribution - NonCommercial — NoDerivativeWorks 4.0 License. ISSN 1824-2049. Published by SISSA Medialab. jcom.sissa.it 